Heribert Adam, the most outstanding non-South-African expert on South Africa, are all worth perusing, but his South Africa without Apartheid, co-authored with Kogila Moodley (1986) is especially worth recommending. Robert M. Price's (1991) The Apartheid State in Crisis is an excellent analysis of political change from 1975 to 1990 . L. H. Gann and Peter Duignan's (1991, ix) Hope for South Africa? is a controversial "conservative" interpretation of South Africa, which the authors themselves describe as differing "radically from the regnant academic orthodoxy." And, at the risk of immodesty, I should like to add my own Power-Sharing in South Africa (Lijphart 1985).

All of the books mentioned so far have been published in the United States and are, therefore, easily accessible for American teachers and students. In addition, of course, there are many relevant publications that have appeared in South Africa. Two that I should like to single out are Critical Choices for South Africa, edited by Robert Schrire (1990), the first of a series of books on the main issues facing the country in the 1990s, and Politikon, the official journal of the Political Science Association of South Africa, issued twice a year since 1974.

\section{References}

Adam, Heribert, and Kogila Moodley. 1986. South Africa without Apartheid: Dismantling Racial Domination. Berkeley: University of California Press.

Ellis, Stephen, and Tsepo Sechaba. 1992. Comrades against Apartheid: The ANC and the South African Communist Party in Exile. Bloomington: Indiana University Press.

Gann, L. H., and Peter Duignan. 1991. Hope for South Africa? Stanford: Hoover Institution Press.

Giliomee, Hermann. 1992. "Broedertwis: Intra-Afrikaner Conflicts in the Transition from Apartheid." African Affairs 91: 339-64.

Hanf, Theodor, Heribert Weiland, and Gerda Vierdag. 1981. South Africa: The Prospects of Peaceful Change. Bloomington Indiana University Press.

Horowitz, Donald L. 1991. A Democratic South Africa? Constitutional Engineering in a Divided Society. Berkeley: University of California Press.

Lijphart, Arend. 1991. “The Alternative Vote: A Realistic Alternative for South Africa?"' Politikon 18: 91-101.

Lijphart, Arend. 1985. Power-Sharing in South Africa. Policy Papers in International Affairs, No. 24. Berkeley: Institute of International Studies, University of California.

Lodge, Tom, Bill Nasson, Steven Mufson, Khehla Shubane, and Nokwanda Sithole. 1991. All, Here, and How: Black Politics in South Africa in the 1980s. South Africa UPDATE Series. New York: Ford Foundation and Foreign Policy Association.

MacDonald, Michael. 1992. "The Siren's Song: The Political Logic of Power-
Sharing in South Africa." Journal of Southern African Studies 18: 709-25.

Ottaway, Marina. 1991. "Liberation Movements and Transition to Democracy: The Case of the A.N.C." Journal of Modern African Studies 29: 61-82.

Price, Robert M. 1991. The Apartheid State in Crisis: Political Transformation in South Africa, 1975-1990. New York: Oxford University Press.

Schrire, Robert. 1991. Adapt or Die: The End of White Politics in South Africa. South Africa UPDATE Series. New York: Ford Foundation and Foreign Policy Association.

Schrire, Robert, ed. 1990. Critical Choices for South Africa: An Agenda for the 1990s. Cape Town: Oxford University Press.

Study Commission on U.S. Policy Toward Southern Africa. 1981. South Africa: Time Running Out. Berkeley: University of California Press.

Welsh, David. 1991. "The Outlook for a Democratic South Africa." International Affairs 67: 739-53.

\section{About the Author}

Arend Lijphart is professor of political science at the University of California, San Diego. His main field of interest is comparative politics, with an emphasis on ethnically divided societies, democratic institutions, and electoral systems.

\title{
Making Political Activity a Requirement in Introductory Political Science Courses*
}

\author{
James D. Chesney, Wayne State University \\ Otto Feinstein, Wayne State University
}

$\mathbf{K}$ nowledge of and participation in America's political institutions is at an abysmal level. Those between 18 and 25 are particularly unlikely to participate in political activity. It is difficult to see how the major issues confronting America domestically and internationally can be dealt with in the context of a massive state of civic illiteracy.

As one vehicle for combating civic illiteracy, as an introduction to polit- ical participation, and as a mechanism for teaching political skills, we have developed a political activity project as a component of our Introduction to American Government course at Wayne State University. Our model assumes that informed political participation changes the participant and improves the capacity of the political system to solve problems. It is also based on the idea that civic literacy and participation in the political process require information regarding basic issues and political structures as well as political skills derived from experience.

Informed participation is crucial. The system's ability to start dealing with key issues then encourages further participation leading to civic literacy.

In order to implement this concept, students in our classes are required to earn at least $25 \%$ of their 
grade from any of three activities: (1) identifying an issue agenda and convening an agenda convention; (2) helping with voter registration and voter participation projects; and (3) interviewing candidates about agenda issues. We view these activities as building two essential skills: coalition building and political mobilization.

\section{History and Background}

We introduced three projects into the curriculum of the required American government courses in 1987: creating an Urban Agenda by the students and including their friends and relatives; organizing a massive voter registration drive, linked to the educational aspect of the Urban Agenda; and, finally, organizing job interviews for presidential candidates regarding the Urban Agenda.

In 1991 we decided to test our model a second time. In the fall, 500 students (as part of the American government course) developed and endorsed a nine-point Urban Agenda and asked the students who would be taking the course in winter 1992 to initiate a voter education/registration effort based on the agenda. Over 1,000 students became involved in this follow-up effort. As a result, 600 political science and school of education students and their friends became deputy voter registrars, registering 3,000 new voters within two weeks. They then organized a second Urban Agenda Convention with 1,250 participants which amalgamated the agenda with that of the National League of Cities. The convention was covered by local news media and videotaped for rebroadcast on the local cable channel, and it was endorsed by the city council of Detroit and the board of commissioners of Wayne County.

The second Urban Agenda Convention also voted to set up April Action Week for voter registration/ education with a target of 3,000 additional new voters. The Detroit Public Schools, the Roman Catholic Archdiocese, the Detroit Baptists, Southeast Michigan Municipal and County Officials, New Detroit, Inc., United Auto Workers, the City of Detroit, and others endorsed the project and continue to participate.

The Urban Agenda, as amended, consists of the following 12 items: health care, education, jobs and employment, crime, environment, economy and budget, civil rights, drugs, social services/homelessness, infrastructure, children at risk, and federal/local partnership. The Urban Agenda does not advocate specific solutions nor endorse candidates. It does urge that these agenda items be put on the electoral agenda and that there be an effective voter registration and education process for young Americans.

By the fall semester of 1992, some 20,000 new voters were registered and a region-wide voter education network (using a daily cable channel) was fully functional. Since the spring convention, the students have interviewed over 300 local elected officials, $85 \%$ of whom offered to provide some support for the Urban Agenda. Working with community groups, students also established 50 Voter Participation Centers and distributed voting information to get out the vote on Election Day. The students are learning how to build coalitions.

\section{Administration}

One major obstacle to a political participation requirement is the logistics of measuring and recording student work on the project. We solve this problem by assigning points to specific, easily measured activities, such as securing completed voter registration cards or participating in meetings to organize activities. The instructor can determine what percent of the grade the political participation module is worth (we have used between $25 \%$ and $40 \%$ ). Under this system, a student determines what combination of activities to use to accommodate the necessary points. During the winter 1992 term, points could be earned in the following ways:

1 point-for each voter registered (maximum of 5 points);

2 points-for each hour logged working on an established registration drive;

5 points-for participation in the steering committee for the oncampus voter registration drive or the Urban Agenda Convention;
5 points $-2-3$ page summary of the project experience: describe your participation, what your goals were, what was accomplished, and what you learned (this activity is required);

5 points-for conducting 5 survey interviews;

1 point-for attending and one point for each guest attending the Urban Agenda Convention (up to 5 points).

The political science classes that used the political activity module met for lectures three days a week and for discussion once a week. The discussion sections were led by teaching assistants who were able to encourage, organize, and monitor student activity.

A central component of this module is the training and swearing in of our students as deputy voter registrars. In Michigan, voter registration is a function of the county clerk's office. The success of our effort is due in large measure to the Elections Division of the Wayne County Clerk's Office. To date, a three-step process has resulted in over 600 students becoming deputy voter registrars:

Step 1: students fill out deputy voter registrars application forms;

Step 2: training session occurs during a lecture period. The training stresses the legal requirements of voting and jurisdiction boundaries;

Step 3: students are sworn in as deputy voter registrars and receive a photo ID from Wayne County.

The whole process was accomplished in two lecture periods of 50 minutes each.

\section{Evaluation}

A careful reading of student reports provides a qualitative evaluation of their experience. The students' reactions are overwhelmingly positive. One student wrote, "I enjoyed the project and the class very much, and I feel my knowledge of politics has increased greatly." Students did not expect the level of public apathy they encountered. According to one student, "We were 
shocked to find that students were not aware of what we were doing." Another commented, "Large numbers of citizens are apathetic toward government and think they can not change the system."

Our goal, to create politically aware and active students, is reflected in several student comments. One student said, "I plan to continue this drive on a personal level by registering my friends and relatives, and members of the union my husband is affiliated with. I think we can make a difference." Another student summarized the project's impact this way, "Now I understand the significance of the voting process, which honestly, had not been important to me before. My first voting experience will be in the March 17 Michigan primary." The connection between voting and the participation project is clear in this student's comment, "I even voted for the first time this semester. If not for this project, I probably would not be registered to vote, and I would have lost the opportunity to vote in the Michigan primary." Finally, students realized they had created a political resource noticed by political leaders. As one student said, "The registration of this many people did get the attention of local civic, religious, and political leaders."

In order to assess qualitatively student reaction to the political activity requirement, we surveyed 286 students who participated in the course. We also surveyed a control group of 32 students who were registered for "Introduction to American Government" (Political Science 101) courses at Wayne State University which did not require the political participation project.

Student reaction to the project was very positive. Eighty percent $(n=250)$ of the students answered "yes" when asked, "Would you recommend having a similar political activity project the next time this course is offered?" Conversely, when asked if the project was a waste of time, only $16.8 \%$ said "yes."

The majority of students felt the amount of time required for the political activity project was about right (63.3\%). Almost 30 percent $(28.3 \%)$ responded that the amount of time spent on the project was too much, and $8.4 \%$ responded that the time was too little. These results reflect the student enthusiasm observed during the voter registration drive and issue convention.

One student criticism of the course organization which emerged from our survey is on the issue of how much of the grade should be based on the political activity project. Almost $65 \%$ of the students $(64.8 \%)$ thought the project should constitute $25 \%$ or less of their grade. The remaining $35 \%$ felt the project should count for more than $40 \%$ of their grade.

The most critical question is whether the students who participated in the project are more or less likely than other political science students to engage in political activity during or after the course. To answer this question, we compared the responses of students in the project with a control group of introductory American Government (PS 101) students who were enrolled in classes that did not require political activity.

In order to gauge political activity, we asked students a series of questions including: whether or not they voted in the Michigan Presidential Primary election that occurred during the semester the course was offered; whether they expected to "engage in political activity after this course is over"; and whether they "will ever work in an election campaign."

Table 1 compares the responses of students involved with the political activity project with students who were not part of the project. Several cautions are necessary in interpreting these responses. First, the classes that used the political activity project are large classes while the control group classes tend to be smaller. Second, as a result of smaller control group classes, the control group is much smaller than the group of students who participated in the project. These cautions mean that the results in Table 1 must be treated with care.

There is a slight tendency for students in political activity classes to more frequently report voting in the Michigan primary election $\mathbf{4 5 . 5 \%}$ for participants and $31.3 \%$ for the control group as shown in Table 1). This difference is a disappointment given the class emphasis on voter registration/voter education in conjunction with the Michigan presidential primary. There is even less difference between control and participant groups on whether students will engage in campaign activity in the future.

When asked the less specific question about further political activity, project participants were more likely to view themselves as participating in politics in the future $\mathbf{5 8 . 4 \%}$ for project participants compared to $\mathbf{3 7 . 5 \%}$ for the control group). We conclude from these results that the political activity requirement may increase the probability of future political activity, but we cannot specify the type or amount of that activity at this point.

\section{Conclusion}

Our experience with the political activity module leads us to the conclusion that it is a worthwhile addition to introductory level political

\section{TABLE 1}

Political Activity Project Participation by Reported and Expected

Political Activity

\begin{tabular}{llc}
\hline & \multicolumn{1}{c}{$\begin{array}{c}\text { Percent Responding "Yes" } \\
\text { for Each Political Activity }\end{array}$} \\
\cline { 2 - 3 } $\begin{array}{l}\text { Reported and Expected } \\
\text { Political Activity }\end{array}$ & $\begin{array}{c}\text { Political Activity } \\
\text { Project Participants } \\
(\mathrm{N}=286)\end{array}$ & $\begin{array}{c}\text { Control Group } \\
(\mathrm{N}=32)\end{array}$ \\
\hline A. Did you vote in the Michigan Primary on March 17, & $45.5 \%$ & $31.3 \%$ \\
$\begin{array}{l}1992 ? \\
\text { B. Do you expect to engage in any further political } \\
\text { activity after this course is over? }\end{array}$ & 58.4 & 37.5 \\
C. Do you think you will ever work in an election \\
campaign?
\end{tabular}


science courses. Political science courses have students and faculty from all parts of their communities with linkages to similar participating institutions and organizations as we have in Detroit. We would like to share our experience with faculty from other universities.

This project has the power to make a substantial difference in voter registration and voter education. If we can identify 100 colleagues who are willing to register 2,000 voters each, we will produce 200,000 newly registered voters and 20,000 politically active voters who are 18-25 years old.

If you want more information, please contact us either by writing (Department of Political Science,
2040 FAB, Wayne State University, Detroit, MI 48202) or phone (313577-2630).

\section{Note}

*Many people helped to make this effort a success. We are grateful to the following Teaching Assistants who were critical to the success of the project: Cynthia Duquette, Charito Melesky, Anthony Perry, Brian Drake, and Elizabeth Masha.

We are also grateful for support from the political science department (notably Darthy

Vasquez and Charles Elder), Shanon McCormick, Wayne County Commissioner George Cushingberry, Veronica Massey from the Wayne County Clerk's Office, The National Rainbow Coalition, New Detroit, Inc., and the United Automobile Workers Union.

\section{About the Authors}

James Chesney is co-director of The Civic Literacy Project at Wayne State University. $\mathrm{He}$ is the former director for research services of the Commission on Professional and Hospital Activities. His publications include "Utilization Trends Before and After Prospective Payment Systems" (Inquiry); "The Effect of Prospective Payment System on Hospital Product and Productivity"' (Health Care Financing Review); "Citizen Participation on Regulatory Boards" (Policy and Law); and "The Impact of Analytic Ability on Congressional Behavior' (Journal of Political Psychology).

Otto Feinstein is professor of political science at Wayne State University and codirector of The Civic Literacy Project. His most recent publications include Appeasing Fascism, which examines the Munich Accords 50 years later; "Institution Coalition Building and the Use of the Media in Relation to Unemployment" in Forrester and Ward's

Unemployment and Training: Case Studies from North America and Europe; and "University Adult Education, Social Issues and Voluntary Association: Some Case Studies From Detroit" in Katus's Democracy and Voluntary Association. 